\title{
COLLABORATING WITH FACULTY TO DESIGN ACTIVE LEARNING WITH FLEXIBLE TECHNOLOGY
}

\author{
Beth A. Fisher, Kathryn G. Miller, \\ William E. Bubro, Deborah J. Frank, Regina F. Frey \\ Washington University in St. Louis
}

Collaboration among faculty and teaching center staff has produced inclass, active-learning methods that belp students learn visualization, problem-solving, critical thinking, and communication skills as they develop disciplinary knowledge. These methods include instructor and student use of technology tools-or tools that are unobtrusive in the classroom, easy to integrate in coordination with "low-tech" tools, and adaptable to multiple pedagogical purposes. Preliminary evaluations suggest evidence of improved learning and high levels of student engagement. Our collaboration has produced insights into teaching and learning that are widely

We thank Hewlett-Packard for supporting this project with two Technology for Teaching Leadership grants (2005 and 2007). We also thank Elizabeth Peterson, Tra'Mel Harrell, Jon Baird, Greg Noelken, and Jason Crow for assistance with classroom technology and Carolyn Dufault, Bryn Lutes, and Michelle Repice for assistance with this chapter. 
applicable, belping to make teaching innovation visible and to transform teaching into an act of scholarship.

Recent scholarship has demonstrated that incorporating active learning into the undergraduate classroom can improve student learning and engagement (Cooper, Cox, Nammouz, Case, \& Stevens, 2008; Eberlein, et al., 2008; Gafney \& Varma-Nelson, 2008; Hockings, DeAngelis, \& Frey, 2008; Michael, 2006; Moog \& Spencer, 2008; Prince, 2004; Yoder $\&$ Hochevar, 2005). However, instructors can be reluctant to incorporate active-learning methods. Reasons for this reluctance vary widely, but commonly include concern that incorporating active learning requires reducing the amount of content taught, lack of experience with planning and facilitating student-centered learning, and unfamiliarity with specific active-learning methods and tools (Bonwell \& Eison, 1991; Michael, 2007; Prince, 2004; Weimer, 2002). Today's university students can also be reluctant to take on more active roles in the classroom, particularly in disciplines in which lecture is the primary instructional method (Bransford, Brown, \& Cocking, 2000; Weimer, 2002).

Similarly, while faculty and students are increasingly using technology in the classroom, both groups remain uncertain as to whether technology improves student learning and engagement. For example, many instructors appreciate the convenience of using technology to disseminate information and communicate with students, but they are skeptical that technology can help students gain disciplinary knowledge (Zhu, 2008). Annual studies conducted since 2004 by the Educause Center for Applied Research have shown that undergraduates share with their instructors the perception that technology offers convenient tools for communicating and sharing information, but does not necessarily improve their learning or increase their engagement in courses (Dahlstrom, de Boor, Grunwald, \& Vockley, 2011; Smith \& Caruso, 2010). Students report that many of their instructors do not use technology effectively. However, they rate their instructors' effectiveness more highly when the use of technology "extend[s] learning beyond the classroom," gives them "control over [their] own learning," and "better prepare[s] [them] for the workforce" (Dahlstrom et al., 2011, p. 24).

A need clearly exists for institutional support for faculty who would like to incorporate active learning into their courses and are interested in exploring whether technological tools can facilitate in-class learning of disciplinary knowledge, as well as meaningful, transferable skills. 
We have responded to this need by collaborating with faculty to design and implement active-learning methods in which instructors and students use flexible technology tools-those that are unobtrusive in the classroom, easy to integrate in coordination with low-tech tools, and adaptable for multiple pedagogical purposes. These tools include SMART Boards, tablet PCs, and a wireless network. Preliminary evaluation of course innovations suggests evidence of improved learning and high levels of student participation and satisfaction. Moreover, the process of working with these instructors has produced insights that teaching center staff have shared with faculty and graduate students from across the disciplines-and with a broader public through the Teaching Center's Web site. This process has also produced recommendations for faculty developers on how to collaborate with faculty to incorporate active learning with flexible technology. Finally, this process is helping to transform teaching into community property at our university (Shulman, 1993).

\section{Consultation as Collaboration}

The Teaching Center at Washington University combines two areas of expertise that are often housed in separate university offices: pedagogical development programs for faculty and graduate students and classroom technology services. The diverse expertise represented in our Teaching Center, combined with the expertise of faculty who are dedicated to improving teaching and learning, create fertile ground for the development of innovative and effective instructional methods.

The innovations described in this chapter originated in two series of faculty consultations-one with a professor of chemistry and one with a professor of biology. Each sought the advice of our center director, $R$. Frey, to redesign a course after realizing that there was a disconnect between what each wanted their students to learn and what their students were actually learning. Both professors consulted with Frey to understand this disconnect and to redesign their instructional methods to help students build the knowledge and skills that each saw as essential to the course in question. Initial consultations focused on articulating the course learning objectives and discussing the evidence that students were not obtaining those objectives. Subsequent discussions, occurring over multiple semesters, resulted in a gradual shift away from a traditional lecture format to a format that included multiple methods, including active learning with flexible technology tools. 


\section{Two Examples}

In this section, we present a condensed account of each course redesign; more comprehensive descriptions of the active-learning methods employed in these two courses are available online (http://teachingcenter. wustl.edu/flexible-technology).

\section{Solid-State and Materials Chemistry}

This course for advanced undergraduates and beginning graduate students in chemistry and engineering has been taught since the late 1990s by W. E. Buhro. The course includes an overview of solid-state crystal structure and materials synthesis, and the course goals include teaching students how to visualize the structures of solid-state materials and understand the connection between a solid-state material's structure and its properties. In the sciences, as in many other disciplines, visualization skills are critical to building conceptual knowledge. In Solid-State and Materials Chemistry, the instructor and students use PowderCell, computer-modeling software, to generate and rotate digital images of solid-state structures. They also use this software to perform refinement exercises, in which they identify unknown materials by analyzing their structures (http://www.ccp14.ac.uk/ccp/web-mirrors/powdcell/a_v/v_1/ powder/e_cell.html).

The integration of active learning and technology into Buhro's course took place in three phases. During the first phase, Buhro began demonstrating PowderCell on the SMART Board, and students were responsible for downloading and using the software outside class. Although PowderCell is easy to download and use, Buhro found that few students used the software outside class and instead used less effective methods to solve the homework problems. Concerned that the students' failure to use PowderCell hindered their development of visualization skills, Buhro consulted with Frey, who suggested that students learn to use PowderCell in class with laptops or tablet PCs. This innovation constituted the second phase. During the third phase, Buhro added in-class, problem-solving refinement exercises. Some students chose to work in pairs to complete the exercises; hence, a one-to-one student-laptop ratio was not necessary.

Buhro's use of the SMART Board worked in tandem with student use of the tablet PCs. Demonstrating how to use PowderCell on the SMART Board, rather than on a computer connected to a data projector, made it easier for the students to see-and to emulate-how Buhro 
was manipulating the software. Furthermore, because students were simultaneously watching Buhro and working on their own laptops or tablet PCs, they were able to put into practice the skills and procedures Buhro was demonstrating, in an atmosphere in which they could ask questions and continue to improve on their work. In addition, Buhro could assess student learning and make adjustments as needed.

Even as he integrated technology, Buhro continued to use the chalkboard to document the verbal explanations, formulas, and diagrams that he expected students to include in their notes. In addition, as he incorporated increasing amounts of active learning and technology, Buhro developed a more interactive teaching style, with frequent opportunities for questions and discussion. As they used PowderCell to perform the visualization and refinement exercises, his students actively took notes, asked and answered questions, and consulted with one another. Because tablet PCs are small, students were able to move easily between using the tablets and taking notes in their notebooks, just as Buhro moved easily between SMART Board and chalkboard.

Preliminary evaluation suggests that introduction of in-class, activelearning exercises using the SMART Board and tablet PCs in Solid-State and Materials Chemistry increased student learning, satisfaction, and participation. During the second phase (2006), when students used PowderCell in class, they were more likely to use PowderCell to complete out-of-class homework exercises. During the third phase (2007 and 2009), Buhro observed that adding in-class problem solving using the tablet PCs with the SMART Board led to improvements in homework scores (Figure 21.1).

Buhro also observed that students asked and answered questions more often when the tablet PCs were introduced in 2006. When he added inclass exercises in 2007, he observed that the increased student participation continued throughout the semester, even when tablet PCs were no longer used. Buhro postulates that using the tablets had an ice-breaker effect. When the students were learning to use PowderCell, they became comfortable asking about the technology. As a result, they were more likely later in the semester to ask questions about the chemical concepts.

End-of-semester surveys administered in 2006 and 2007 show that students perceived that using the tablet PCs improved their understanding of the concepts (Figure 21.2). In 2007, when in-class refinement exercises were added, the average response to statement 3 (I am more comfortable working computer exercises outside of class because I used tablet PCs in class) increased to 4.5 (on a five-point scale) over an average of 4.1 in 2006. 


\section{Figure 21.r. Average Score on the Refinement Homework Assignment in Solid-State and Materials Chemistry.}

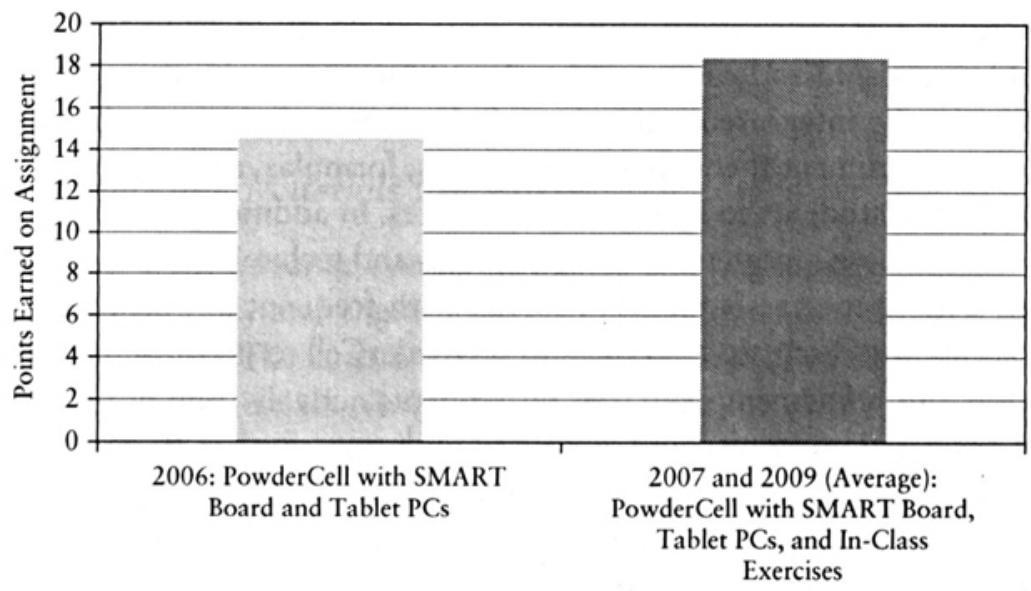

Figure 2 1.2. Student Perceptions of Tablet PCs in Solid-State and Materials Chemistry (Average Values, Spring 2006 and Spring 2007).

Lickert Scale

$5=$ Strongly

Agree

$4=$ Agree

$3=$ Neutral/Uncertain

$2=$ Disagree

$1=$ Strongly

Disagree

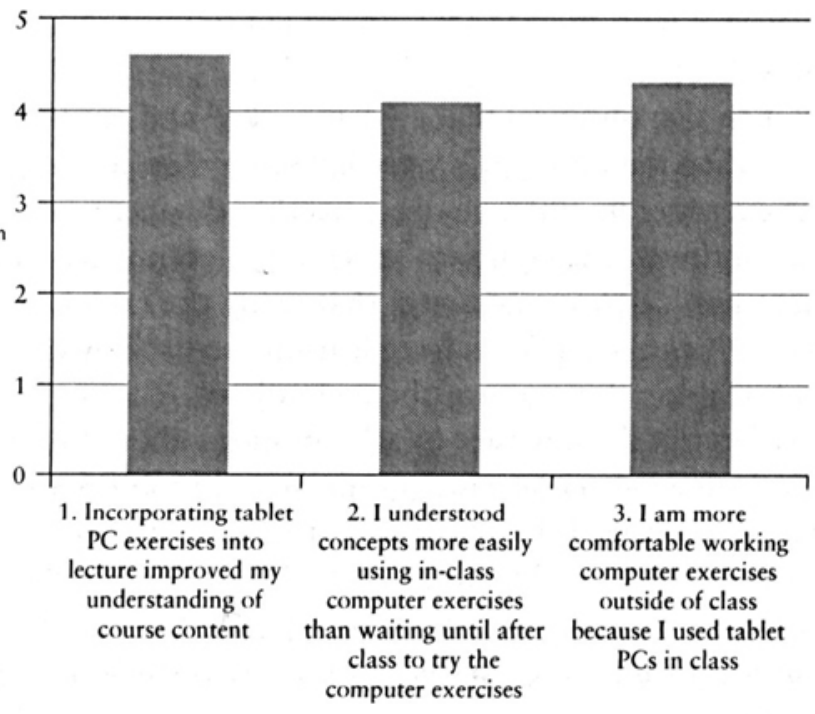


The integration of active learning and flexible technology into SolidState and Materials Chemistry has led to a gradual but profound course transformation. Students gain hands-on computer-modeling experience combined with visualization and problem-solving skills that are essential to their understanding of solid-state structures and to their future course work and research. Increased student participation and collaboration, along with improved homework scores, have convinced Buhro of the effectiveness of active learning with the SMART Board and the tablet PCs.

\section{Molecular Mechanisms in Development}

This upper-level, writing-intensive biology course has been taught since the mid-1990s by K. G. Miller, and it was cotaught between 2008 and 2011 with D. J. Frank. One of Miller's goals for the course is to teach students not only "what we know" about developmental biology, but also "how we know what we know"-or how new knowledge is produced through laboratory research. This vision of science as a process of discovery informs the teaching goals of many science faculty. Another course goal relevant across many disciplines, including the humanities and social sciences, is to teach students how to integrate facts into broader ideas and arguments.

Early on, Miller realized that her students tended to demonstrate their knowledge by listing facts rather than by synthesizing facts into broader arguments. Therefore, she began to redesign the course in a writingintensive format - a process that began with her participation in the Teaching Center's workshops on teaching with writing and continued in a series of consultations with Frey. The result of these consultations was a redesigned course in which students no longer took exams but instead wrote a series of essays in which they presented and supported arguments about current research articles in developmental biology.

The course redesign process continued as Miller moved away from a traditional lecture format toward a format combining lecture and discussion. After using the SMART Board to diagram experiments and document ideas generated during class, she found that her active engagement with the material led her students to be more actively engaged. She developed a series of questions that she could project on the SMART Board when starting the discussion of each article. The SMART Board provided a means of displaying these questions and documenting students' answers, with annotations that could be saved and distributed to the students using the wireless network, e-mail, or the learning management system (Figure 21.3). Repeated use of these questions allowed Miller to teach her students a structured habit of questioning that they 
Figure 21.3. Annotated Slide from Molecular Mechanisms in Development.

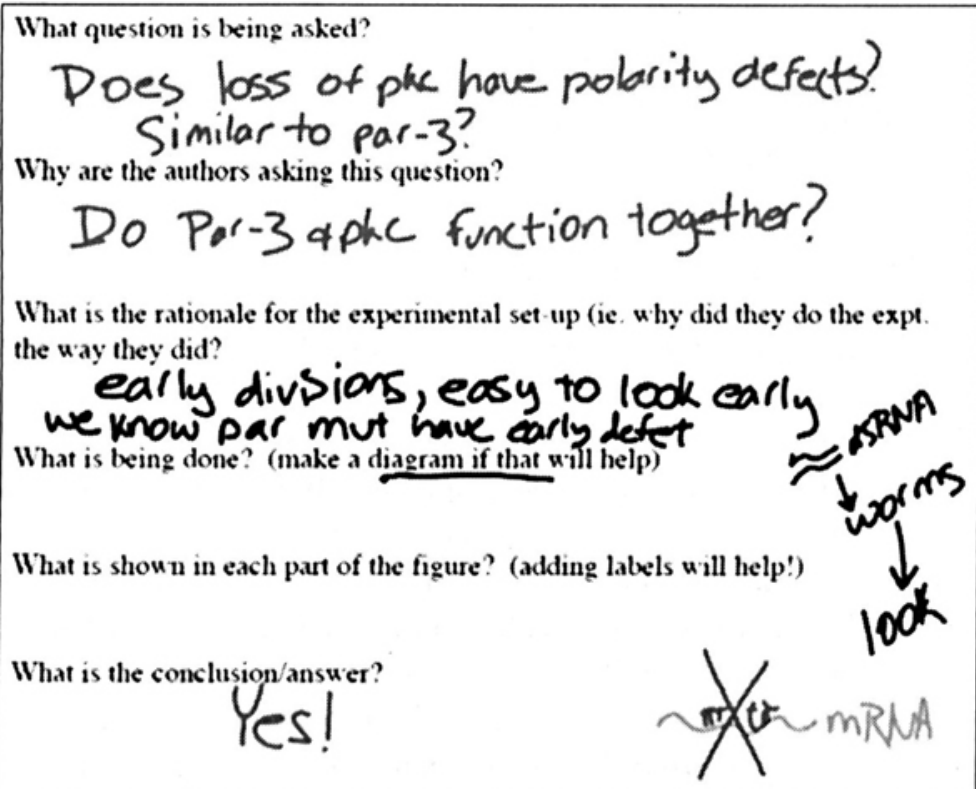

Note: To see this figure in color, go to bttp://teachingcenter.wustl.edul flexible-technology/bio.3191/questioning

could use whenever they read and wrote about scientific literature-both during and outside class.

Miller also used the SMART Board to annotate figures from research articles, thereby modeling another form of annotation that students could emulate. Miller observed that her capacity to annotate figures on the SMART Board during class encouraged her students to annotate and think about the figures. After a preliminary phase in which Miller's students annotated the slides on black-and-white handouts, Miller worked with Frey to integrate student use of tablet PCs for this purpose. With this innovation, students could use the tablet PCs and take notes on slides that Miller made available to students using the learning management system. Initially students were trained by Teaching Center staff on how to use tablet PCs during the first week of class. More recently, instructors have provided training during active-learning activities 
designed for the opening week. Throughout the process, Teaching Center staff prepared technology "help sheets" for the instructors and the students.

We have found that annotating with the SMART Board and tablet PCs offers four major advantages over other tools such as handouts, chalkboard, and iPads. These advantages are relevant to teaching in a range of disciplines, including science and mathematics, humanities, art and architectural design, and any other course in which students learn to analyze complex visual images or lengthy text passages. First, the figures analyzed in Miller's course are often difficult to reproduce on a chalkboard. Second, the SMART Board and tablet PCs can be used to project the figure as a full-color digital image, crucial in Molecular Mechanisms in Development because laboratory techniques often use color to indicate important information (for example, immunofluorescence to show localization of proteins). Third, both the SMART Board and tablet PCs allow users to annotate using multiple colors and save the annotated slides in electronic files that students and instructors can access outside class and that instructors can refer to when preparing to teach the course in future semesters. Fourth, when the instructor is working at the SMART Board, the students can observe her making annotations directly on the projected slides or figures. Just as in Solid-State and Materials Chemistry, this capacity makes it easier for students to follow, emulate, and refine the instructor's annotations than it would be if the instructor were annotating on a document camera or a tablet device, such as an iPad, at the instructor's desk while students were watching the annotations appear on a projection screen.

In the next phase of course redesign, Miller increased opportunities for active learning by incorporating in-class, small group discussions during which students built knowledge collaboratively through peer discourse. After developing group work with Frey in 2008, Miller has added more group work every year. In 2009, Frey suggested using a wireless network, allowing students to present their annotations to the class using a data projector.

During a typical discussion, Miller divided the students into groups of four or five and assigned to each group a figure from the day's article and displayed on the SMART Board two or three questions, such as, "What is shown in this figure?" and, "How does this figure support the authors' thesis?" She gave the groups ten to twelve minutes to annotate the figure and answer the questions and then asked a spokesperson from each group to explain the annotations, which were projected using the wireless network (Figure 21.4). During group discussions, students engaged in 
Figure 2 I.4. Figure Illustrating a Direct Physical Interaction

Between Two Proteins of Interest, Annotated by a Student During a Small Group Discussion.

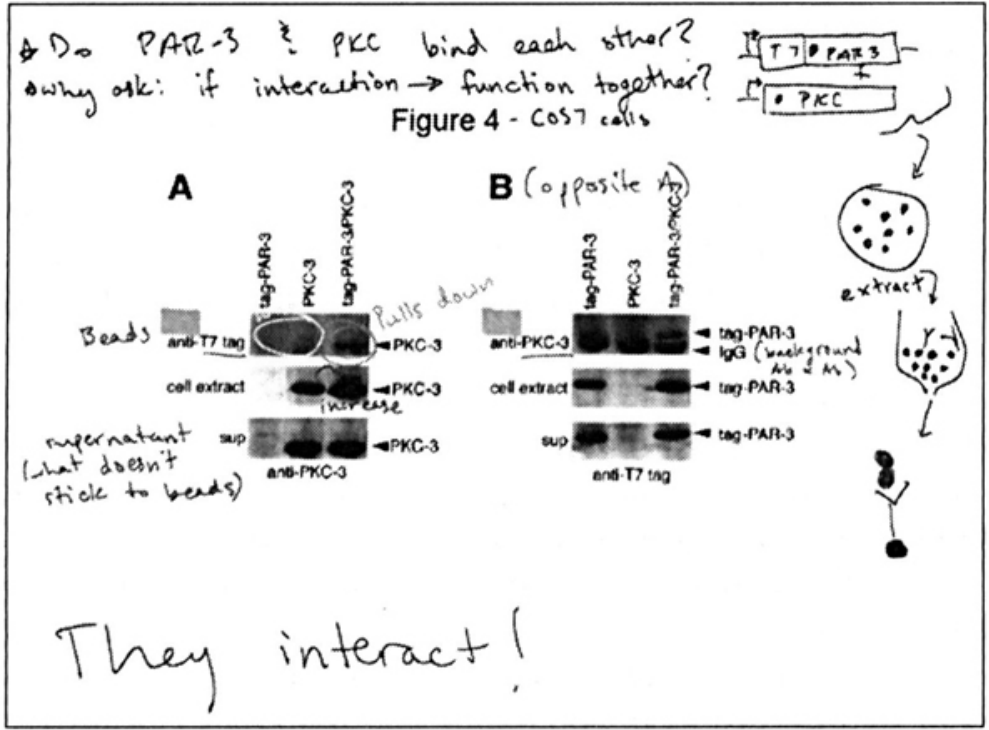

Note: To sec the figure in color, go to bttp://teachingcenter.wustl.edu/ flexible-technology/bio.3191/group-work

Source: Tabuse et al. (1998). Reproduced and adapted by permission of The Company of Biologists Ltd. http://dev.biologists.org/content/125/18/3607

$$
\text { .full.pdf+btml }
$$

thinking out loud as they explained the factual research findings and how those findings supported the authors' arguments.

Using the SMART Board in combination with tablet PCs during class has been instrumental in helping students in Molecular Mechanisms in Development build critical thinking, argumentation, and communication skills that they further develop when writing essays on current laboratory research. Miller and Frank have observed that in-class use of the SMART Board and tablet PCs has increased student participation and engagement. Postsemester perception surveys administered in fall 2008 and 2009 demonstrate that students perceived active learning with flexible technology to improve their learning and engagement (Figure 21.5). In addition, students believed that tablet PCs enabled them to take an 


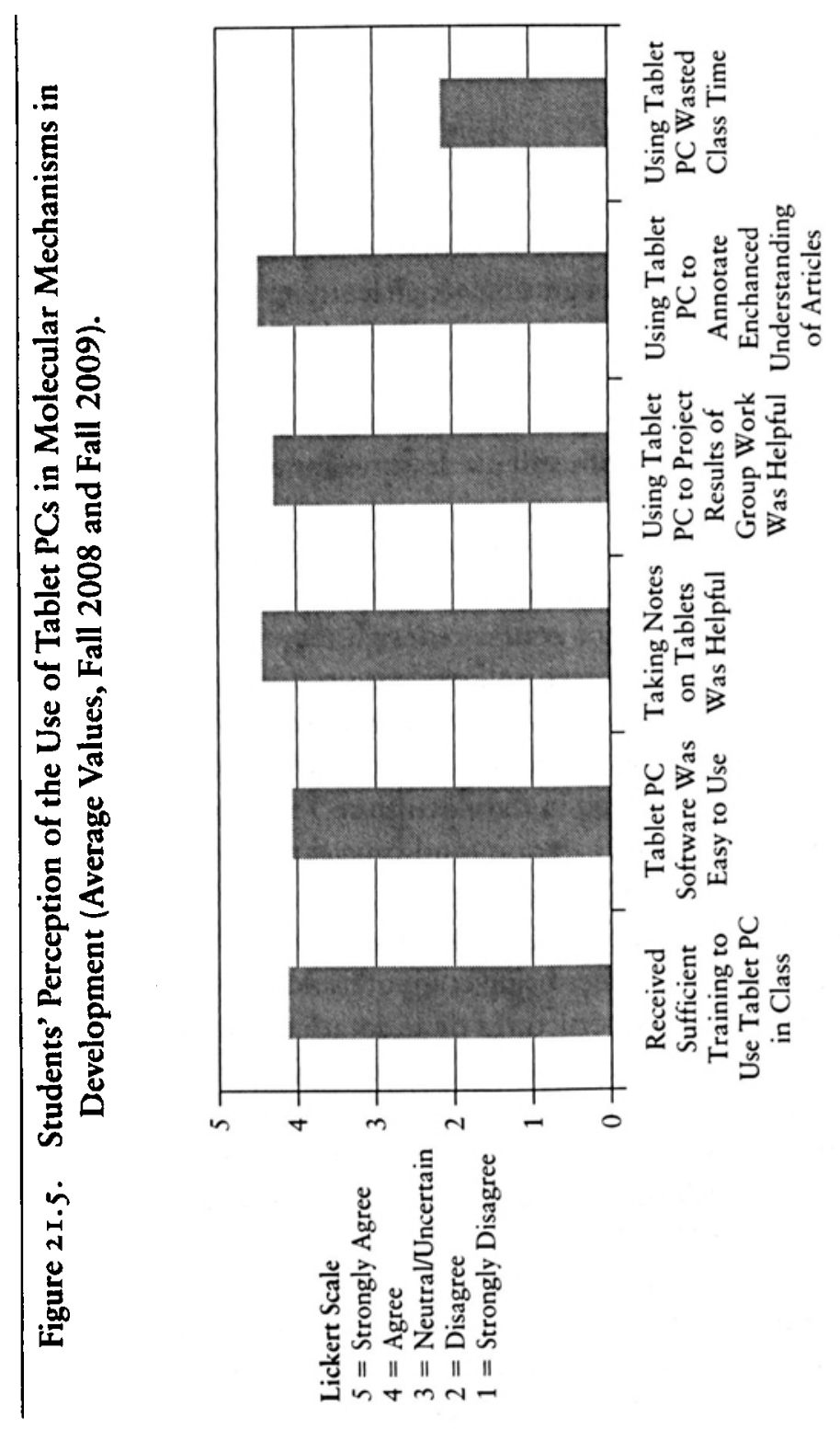


active role in class and to create personalized annotations that reflected their evolving knowledge of developmental biology. These preliminary results, along with instructor observations of improved learning, have led Miller and Frank to design a more formal evaluation of their instructional methods in a study that is currently under way.

\section{Reflections on Active Learning with Flexible Technology}

Variation among the methods implemented in these two courses suggests that the Teaching Center's collaboration with faculty to develop an incremental approach to integrating active learning is versatile enough to fit a variety of pedagogical purposes and teaching styles. Furthermore, both instructors introduced active learning incrementally, over an extended period of time, allowing them to blend active learning into their respective teaching styles. Both still use lectures for a number of purposes, such as introducing new content, making connections between new and prior knowledge, and helping students refine knowledge and skills developed during active-learning activities. Gradual integration of active learning has made the process of course redesign more manageable and allowed each instructor to observe and evaluate results of each innovation and make adjustments based on these evaluations.

The SMART Board and tablet PCs are flexible tools that can facilitate hands-on active learning in the classroom. The former allows the instructor to move around the room and interact with students rather than remain behind a computer. In addition, when the instructor uses the SMART Board, students can readily follow and emulate his or her use of the technology-whether using computer-modeling software to visualize and analyze chemical structures or annotating figures to analyze research articles. Student use of tablet PCs, in coordination with the instructor's use of the SMART Board, allows students to immediately put into practice and then refine the skills that the instructor is modeling. The tablet PCs do not block the students' views of the instructor (or vice versa), or of one another. Therefore, tablet PCs do not hinder interaction among the students or between the instructor and students, as is often the case in a classroom with desktop computers, where students are often working with their backs to the instructor or working behind large monitors, thereby making it difficult for the instructor and students to see each other. Whereas using technological devices in the classroom can increase communication barriers, using tablet PCs in active-learning activities appears to break down such barriers, whether perceived or physical. Students find tablet PCs easy to use and preferable to using paper 
notebooks in some cases. At the same time, the small size of the tablets means that the students can easily move between using them and taking notes on paper and between taking notes and participating in group discussions.

This process has demonstrated that flexible technological tools can benefit a diverse range of students and courses, and it has produced methods that may be implemented with a variety of high-tech and low-tech tools. We have found that the flexibility of these tools and the design of multimedia in our classrooms increases the cost-effectiveness of instructional technology. Moreover, as university-specific data from the 2011 Educause Center for Applied Research (ECAR) study demonstrate, our undergraduates rate the technology skills of their instructors more highly than do undergraduates nationally ( $\mathrm{S}$. Grajek, personal communication, July 26, 2011).

The active-learning methods used in these two courses have led students to develop meaningful and transferable technology skills as they learn disciplinary knowledge. These methods include authentic tasks, such as manipulating widely used computer-modeling software and analyzing and explaining complex figures and arguments. We believe that these authentic uses of technology have immediate relevance and intrinsic interest for students. The postsemester survey results suggest that students in each course perceived the active-learning strategies and use of technology as integral to the course and to their learning within and beyond the course. Survey results also confirm national ECAR data demonstrating that undergraduates find instructional technology effective when it allows them to exercise control over their own learning (Dahlstrom et al., 2011, p. 24).

\section{Broader Impact: Dissemination and Adaptation}

In addition to descriptions of the instructional methods that appear on the Teaching Center's Web site (http://teachingcenter.wustl.edu/flexibletechnology), the center has produced six videos, also available on our Web site, in which Buhro and Miller describe their courses, including how they use active learning with flexible technology (http://teachingcen ter.wustl.edu/teaching-strategies/commentaries). Teaching Center staff have incorporated these videos into workshops for graduate students and postdoctoral appointees and into consultations with junior faculty.

Analysis of our Web site use demonstrates that these videos have generated interest within and beyond the university. Moreover, Miller, Frank, and Frey have presented insights from the redesign of these courses to 
interdisciplinary audiences at our university's biennial faculty symposium on teaching. As a result of her role in helping Miller and Frank to document instructional methods employed in Molecular Mechanisms in Development, the Teaching Center's associate director of academic services, B. Fisher, has adapted some of their active-learning methods for her writing-intensive American literature course. For example, her students use tablet PCs, in coordination with the SMART Board and wireless network, to annotate literary texts and historical images and to complete in-class writing exercises.

\section{Recommendations}

The following recommendations are based on our experience collaborating with faculty to design active learning with flexible technology:

1. Start the redesign by assisting the instructor in defining learning objectives or course goals, and then collaborate to identify what students could do during class to build the knowledge and skills identified in those objectives.

2. As you work together to develop specific active-learning activities, recommend integration of these activities with other methods. For example, discuss how the instructor might combine lectures with discussions, problem solving, or group work.

3. Help the instructor develop a plan for gradually integrating active learning. An incremental approach allows the instructor to add a new method, evaluate its effects, and make any necessary adjustments before adding the next innovation.

4. As the use of active-learning strategies increases, assist the instructor in reducing the amount of material taught. Incorporating active-learning methods often means covering less material. Faculty developers can assist with this transition by meeting with an instructor to review lecture notes and identify specific parts of the lecture that convey knowledge students could derive or discover through in-class work, whether individually or in groups.

5. Discuss specific ways in which incorporating active learning can require stepping outside one's comfort zone to develop a more interactive style:

- Address common pitfalls and how to avoid them. For example, help instructors avoid relying solely on lecturing by developing 
strategies to increase student participation, such as sequencing questions from easier to more difficult and allowing students sufficient time to complete active-learning activities and compose thoughtful answers.

- Help the instructor develop active-learning activities that are well designed, clearly structured, and actively facilitated by the instructor. Instructors should give students clear instructions and time limits and should develop specific strategies for integrating results of active learning-from asking students to summarize what they have learned, to asking follow-up questions of each group and the larger class.

- Suggest specific ways to achieve student buy-in from the start of the semester. Familiarize the instructor, for example, with research showing that participation in active learning can lead to deeper learning. In addition, suggest that the instructor explain to students the purpose behind the active-learning strategies and that the instructor incorporate active-learning exercises on the first day of class and frequently thereafter during the first few weeks of the semester.

6. Determine whether technology can provide useful and flexible tools to facilitate active learning. Again, it is best to use multiple tools. We recommend, for instance, that instructors combine use of a SMART Board and tablet devices, or laptops, with low-tech tools such as the chalkboard or handouts. The document camera is another flexible tool that instructors can use to project anything from a printed image to three-dimensional models and demonstrations.

7. Collaborate with classroom technology staff to ensure that the technology is designed to be intuitive and easy to use. In addition, anticipate and plan for technical and logistical issues. These issues include determining what hardware and software are needed, which classrooms are appropriate, whether in-class technical support will be needed (and when), and whether the instructor and students will need training on specific tools or software. Classroom-services staff should also create brief "help sheets" containing essential technical how-tos for the instructor and students.

- Encourage the instructor to allow time before the semester to be trained on any new technology tools and to practice teaching with these tools. 
- With the instructor, develop a plan for providing students with any needed training by the instructor or classroom services staff. Provide training gradually, teaching students what they need to know when they need to know it.

8. Encourage the instructor to evaluate innovations. Evaluation can take a range of forms, all of which faculty developers can assist with-from observing a few classes, to administering a studentperception survey, to developing a formal study evaluating the effects of a teaching innovation.

\section{Conclusion}

We believe that our approach to collaborating with faculty to design active learning using flexible technology has been successful for several reasons. Although these reasons are specific to our approach, they suggest a philosophy that can be readily adapted by faculty developers at other institutions. First, the process is driven by the instructor's specific goals for student learning and interest in finding innovative, effective, and meaningful methods for helping students achieve those goals. Second, consultations with each instructor are truly collaborative-bringing together the rich, discipline-specific experience of each instructor in teaching a particular course with the diverse expertise of Teaching Center staff. Third, the process focuses on the development of active-learning methods that can be integrated with other pedagogical methods and implemented with tools that are flexible and unobtrusive in the classroom. Fourth, the process follows a principle that guides our consultations with faculty who are designing or redesigning a course: new methods and tools should be introduced incrementally to allow gradual adjustments in course content and the instructor's teaching style. By lowering perceived barriers to trying new methods, an incremental approach can lead to profound change over time.

Beyond the improvements in student learning and engagement that we have observed, the success of our approach can be seen in the emergence of what Lee Shulman called "teaching as community property" (1993). The innovations developed by these professors in collaboration with the Teaching Center have transformed teaching into scholarship that can be documented, opened to peer review, evaluated, and improved on. Our collaborative approach to course redesign has not only made visible the innovative and effective teaching of outstanding instructors; it has also extended outward to inspire other faculty and graduate students to explore new and innovative ways to improve teaching and learning. 


\section{REFERENCES}

Bonwell, C. C., \& Eison, J. A. (1991, September). Active learning: Creating excitement in the classroom. National Teaching and Learning Forum. Retrieved from http://www.ntlf.com/html/lib/bib/91-9dig.htm

Bransford, J., Brown, A. L., \& Cocking, R. R. (Eds.). (2000). How people learn: Brain, mind, experience, and school. Washington, DC: National Academy

Press. Retrieved from http://www.nap.edu/openbook.php? record_id $=9853$ Cooper, M. M., Cox, C. T., Nammouz, M., Case, E., \& Stevens, R. (2008). An assessment of the effect of collaborative groups on students' problemsolving strategies and abilities. Journal of Chemical Education, 8.5(6), 866-872.

Dahlstrom, E., de Boor, T., Grunwald, P., \& Vockley, M. (2011). The ECAR National Study of Undergraduate Students and Information Technology, 2011. Boulder, CO: Educause Center for Applied Research. Retrieved from http://net.educause.edu/ir/library/pdf/ERS1103/ERS1103W.pdf Eberlein, T., Kampmeier, J., Minderhout, V., Moog, R. S., Platt, T., VarmaNelson, P., \& White, H. B. (2008). Pedagogies of engagement in science. Biochemistry and Molecular Biology Education, 36(4), 262-273. doi:10.1002/bmb.20204.

Gafney, L., \& Varma-Nelson, P. (2008). Peer-led team learning: Evaluation, dissemination, and institutionalization of a college-level initiative.

New York, NY: Springer.

Hockings, S. C., DeAngelis, K. J., \& Frey, R. F. (2008). Peer-led team learning in general chemistry: Implementation and evaluation. Journal of Chemical Education, 8.5(7), 990-996.

Michael, J. (2006). Where's the evidence that active learning works? Advances in Physiology Education, 30(4), 159-167. doi:10.1152/advan.00053.2006.

Michael, J. (2007). Faculty perceptions about barriers to active learning. College Teaching, 55(2), 42-47. doi:10.3200/CTCH.55.2.42-47.

Moog, R. S., \& Spencer, J. N. (Eds.). (2008). Process oriented guided inquiry learning (POGIL). Washington, DC: American Chemical Society.

Prince, M. (2004). Does active learning work? A review of the research. Journal of Enginecring Education, 93(3), 1-9.

Shulman, L. S. (1993). Teaching as community property: Putting an end to pedagogical solitude. Change, 25(6), 6-7.

Smith, S., \& Caruso, J. (2010). The ECAR Study of Undergraduates and Information Technology, 2010. Boulder, CO: Educause Center for Applied Research. Retrieved from http://net.educause.edu/ir/library/pdf/ers1006/rs/ ers1006w.pdf

Tabuse, Y., Izumi, Y., Piano, F., Kemphues, K. J., Miwa, J., \& Ohno, H. (1998). Atypical protein kinase $C$ cooperates with PAR-3 to establish embryonic 
polarity in Caenorhabditis elegans. Development, 125, 3607-3614. Retrieved from http://dev.biologists.org/content/125/18/3607.full .pdf + html

Weimer, M. (2002). Learner-centered teaching: Five key changes to practice. San Francisco, CA: Jossey-Bass.

Yoder, J., \& Hochevar, C. (2005). Encouraging active learning can improve students' performance on examinations. Teaching of Psychology, 32, 91-95. doi:10.1207/s15328023top3202_2.

Zhu, E. (2008). Breaking down barriers to the use of technology for teaching in higher education. In D. R. Robertson \& L. B. Nilson (Eds.), To improve the academy: Resources for faculty, instructional and organizational development, Vol. 26 (pp. 305-318). San Francisco, CA: Jossey-Bass/Anker. 